\title{
Major Soluble Proteins of Sweet Potato Roots and Changes in Proteins after Cutting, Infection, or Storage
}

\author{
He-sheng LI* and Kazuko ÔBA \\ Laboratory of Biochemistry, Faculty of Agriculture, Nagoya University, \\ Chigusa-ku, Nagoya 464, Japan
}

Received August 10, 1984

\begin{abstract}
Study of the soluble proteins of sweet potato (Ipomoea batatas L. cv. Norin 1) roots showed that the major protein had an apparent molecular weight of 25,000 , and accounted for $60 \sim 70 \%$ of the total soluble protein extracted from fresh tissue. The $25-\mathrm{kDa}$ protein exists in two forms, which can be resolved into two bands by nondenaturing polyacrylamide gel electrophoresis. Immunodiffusion and crossed immunoelectrophoresis showed that these forms are immunologically identical. This protein was identified as the antigenic component A of sweet potato root. ${ }^{1)}$ It was degraded to proteins of lower molecular weight $(9,500$ to 20,000$)$ if the tissue was cut or infected by Ceratocystis fimbriata. As almost none of this $25-\mathrm{kDa}$ protein was detected in roots stored for one year at $10 \sim 12^{\circ} \mathrm{C}$, it is probably the storage protein of these roots. Another major protein was identified as $\beta$-amylase by immunodiffusion and immunoelectrophoresis. The amount of $\beta$-amylase did not change appreciably after cutting or infection, but it was present in only trace amounts in the roots stored for one year, Cutting, infection, or storage of root tissue resulted in the production of new isozymes of peroxidase, acid phosphatase, and esterase. Increases in some other proteins in cut and in diseased tissues were detected by gel electrophoresis.
\end{abstract}

The soluble proteins of sweet potato roots were studied in relation to metabolic alterations in response to pathogenic infection. Uritani \& Stahmann ${ }^{1,2)}$ reported that certain antigenic components are produced in sweet potato root tissue in response to infection by Ceratocystis fimbriata, and designated two of them as components B and D. Other major components, $\mathrm{A}$ and $\mathrm{C}$, are present in all tissue extracts of fresh, cut, or diseased tissues of many varieties of sweet potato. Components $C$ and $\mathrm{D}$ have been identified as $\beta$-amylase and peroxidase A, respectively., ${ }^{1,3)}$ However, the nature of component $\mathrm{A}$, which is present in higher concentrations than most other antigenic components of the extracts, and component $\mathrm{B}$, which appears in diseased tissue in amounts roughly parallel to the magnitude of the resistant reaction of the host tissue, has not been elucidated. We examined the soluble pro- teins of sweet potato roots using polyacrylamide gel electrophoresis and immunochemical techniques.

Little is known about the constituent proteins of most root and tuber storage organs, except for those of potatoes and yams, which have been studied in detail. ${ }^{49)}$ Here, we found a major soluble protein that was degraded into peptides of lower molecular weight after storage, cutting, or fungal infection of the roots.

\section{MATERIALS AND METHODS}

Plant materials. Roots of sweet potato (Ipomoea batatas, L. cv. Norin 1) harvested in autumn were stored at $10 \sim 12^{\circ} \mathrm{C}$ until use. The roots were surface-sterilized with $0.1 \%$ (v/v) sodium hypochlorite and the parenchymatous tissue was sliced $2 \mathrm{~cm}$ thick. Individual roots were cut into two parts. One part was inoculated with a spore suspension $\left(1 \times 10^{7} / \mathrm{ml}\right)$ of Ceratocystis fimbriata Ell. \& Halst and incubated at $30^{\circ} \mathrm{C}$ for $44 \mathrm{hr}$. Sections $(1 \sim 2 \mathrm{~mm}$ thick $)$

* Present address: Department of Plant Physiology, Hua-zhong Agriculture Institute, Wuhan, The People's Republic of China. 
from the non-infected tissue just below the infected part were used as diseased tissue. The other part was incubated under the same conditions without inoculation. Here sections $(1 \sim 2 \mathrm{~mm})$ were taken from the tissue $0.5 \mathrm{~mm}$ below the surface and used as cut tissue. Parenchymatous tissue of whole roots not subjected to inoculation and incubation was used as fresh tissue. Parenchymatous tissue of whole roots stored at $10 \sim 12^{\circ} \mathrm{C}$ for one year was used as stored tissue.

Extraction of soluble proteins from tissues. The tissues $(60 \mathrm{~g})$ were homogenized with $120 \mathrm{ml}$ of $0.05 \mathrm{M}$ potassium phosphate buffer ( $\mathrm{pH} 7.5$ ) containing $0.5 \mathrm{M}$ sucrose, $10 \mathrm{~mm}$ $\mathrm{MgCl}_{2}, 1 \%(\mathrm{w} / \mathrm{v})$ ascorbic acid, and $24 \mathrm{~g}$ of Polyclar AT in a homoblender for $1 \mathrm{~min}$. During the homogenization, the $\mathrm{pH}$ was adjusted to 7.5 with $10 \%(\mathrm{w} / \mathrm{v}) \mathrm{K}_{2} \mathrm{CO}_{3}$. The homogenate was filtrered through two layers of nylon gauze and centrifuged at $9,000 \times g$ for $20 \mathrm{~min}$. The supernatant was passed through a Sephadex G-25 column $(4.5 \mathrm{~cm} \times 40 \mathrm{~cm})$ equilibrated with $0.05 \mathrm{M}$ potassium phosphate buffer ( $\mathrm{pH} 7.5$ ) containing $0.25 \mathrm{M}$ sucrose, $1 \mathrm{~mm}$ $\mathrm{MgCl}_{2}$, and $0.5 \%(\mathrm{w} / \mathrm{v})$ ascorbic acid, to remove polyphenols from the solution. The effluent was centrifuged at $100,000 \times g$ for $2 \mathrm{hr}$, and the proteins in the supernatant were precipitated with ammonium sulfate $(56.1 \mathrm{~g} / 100 \mathrm{ml})$. The precipitate was suspended in $0.05 \mathrm{M}$ potassium phosphate buffer ( $\mathrm{pH} 7.5$ ) containing $12.5 \%(\mathrm{v} / \mathrm{v})$ glycerol and $0.1 \%(\mathrm{w} / \mathrm{v})$ ascorbic acid, and dialyzed against the same buffer for $15 \mathrm{hr}$ with one buffer change, and then for $5 \mathrm{hr}$ against buffer of the same composition but with $0.05 \%$ $(w / v)$ ascorbic acid. The dialyzate was stored frozen at $-20^{\circ} \mathrm{C}$ until use.

Polyacrylamide gel electrophoresis. Sodium dodecyl sulfate (SDS) polyacrylamide gel electrophoresis was done according to $\mathrm{Laemmli}^{10}$ ) on a 1 -mm thick slab of $14.5 \%$ $(\mathrm{w} / \mathrm{v})$ polyacrylamide gel. Protein samples were denatured before electrophoresis by incubation for $20 \mathrm{~min}$ at $70^{\circ} \mathrm{C}$ in $1 \%(\mathrm{w} / \mathrm{v})$ SDS containing $1 \%$ (v/v) 2-mercaptoethanol and $5 \%(\mathrm{w} / \mathrm{v})$ sucrose. Nondenaturing polyacrylamide gel electrophoresis was done according to Davis ${ }^{11)}$ on a $1-\mathrm{mm}$ thick slab of $7.5 \%(\mathrm{w} / \mathrm{v})$ polyacrylamide gel. The current was a constant $10 \mathrm{~mA} / \mathrm{cm}^{2}$. The separated proteins were stained with Coomassie Blue R $250(0.25 \%$ in $\left.\mathrm{MeOH}-\mathrm{HOAc}-\mathrm{H}_{2} \mathrm{O}, 5: 1: 4, \mathrm{v} / \mathrm{v} / \mathrm{v}\right)$. Densitometric analysis of the stained gels was done on a Toyo digital Densitorol (Model DMU-33C).

Zymograms of peroxidase, acid phosphatase, and esterase were prepared by staining the gels according to the following procedure. Peroxidase activity was located by staining the gel for $15 \mathrm{~min}$ at $25^{\circ} \mathrm{C}$ in $0.1 \mathrm{M}$ citrate buffer (pH 5.0) containing $o$-phenylenediamine $(0.4 \mathrm{mg} / \mathrm{ml})$ and $0.01 \%(\mathrm{v} / \mathrm{v}) \mathrm{H}_{2} \mathrm{O}_{2}{ }^{12)}$ Acid phosphatase activity was located by staining the gel for $1 \mathrm{hr}$ at $25^{\circ} \mathrm{C}$ in $0.05 \mathrm{M}$ acetate buffer (pH 5.0) containing $1 \mathrm{~mm} 1$-naphthyl phosphate and Fast Garnet GBC salt $(0.5 \mathrm{mg} / \mathrm{ml}) .{ }^{13)}$ Esterase activity was located by staining the gel for $20 \mathrm{~min}$ at $25^{\circ} \mathrm{C}$ in $0.1 \mathrm{M}$ phosphate buffer (pH 7.0) containing $5 \mathrm{~mm}$ 1-naphthyl acetate, $5 \mathrm{~mm}$ 2-naphthyl acetate, and Fast Blue RR salt $(1 \mathrm{mg} / \mathrm{ml}){ }^{14)}$

Quantitative evaluation of major proteins. The ratio of the amounts of major proteins to the total soluble proteins was determined from quantitative measurements of the amount of dye bound to each protein, obtained by integrating the densitometric scans of gels after SDS polyacrylamide gel electrophoresis.

Preparation of antisera to soluble proteins. Samples each of $15 \mathrm{mg}$ of the total soluble proteins extracted from fresh and diseased tissues were mixed with an equal volume of complete Freund's adjuvant. The mixture was injected twice subcutaneously into a rabbit at an interval of 15 days. Seven days after the second injection, $10 \mathrm{mg}$ of each protein was mixed with an equal volume of incomplete adjuvant and this mixture was injected subcutaneously. The rabbit was bled 9 days after the final injection.

Immunochemical tests. Double immunodiffusion tests were carried out as described by Ouchterlony and Nilson $^{15)}$ on a $1 \%(\mathrm{w} / \mathrm{v})$ agarose plate containing $0.01 \mathrm{M}$ phosphate buffer (pH 7.2), $0.15 \mathrm{M} \mathrm{NaCl}$, and $0.1 \%(\mathrm{w} / \mathrm{v})$ $\mathrm{NaN}_{3}$. The dishes were kept in a moist chamber at $25^{\circ} \mathrm{C}$.

Crossed immunoelectrophoresis was also done according to Ouchterlony and Nilson. First, soluble proteins from fresh and diseased tissues were individually separated by nondenaturing polyacrylamide gel electrophoresis on a $1-\mathrm{mm}$ thick slab of $7.5 \%(\mathrm{w} / \mathrm{v})$ gel $(\mathrm{pH} 8.9)$. Then a strip of this gel $(6 \mathrm{~mm}$ wide) was mounted on a $1 \%(\mathrm{w} / \mathrm{v})$ agarose plate $(5 \times 5 \mathrm{~cm})$ containing both barbital- $\mathrm{HCl}$ buffer $(\mathrm{pH}$ $8.6, \mu=0.02)$ and $3 \%(\mathrm{v} / \mathrm{v})$ antiserum to total soluble proteins from diseased tissue or to band 9 protein (25$\mathrm{kDa}$ ) purified by Dr. M. Maeshima of this laboratory (data will be published elsewhere). A constant current of $5 \mathrm{~mA}$ was applied to the plate for $15 \mathrm{hr}$. After immunoelectrophoresis, the plate was washed and stained with Coomassie Blue R 250.

Protein Determination. Proteins in tissue extracts were precipitated with $10 \%(\mathrm{w} / \mathrm{v})$ trichloroacetic acid (TCA), dissolved in $1 \mathrm{~N} \mathrm{NaOH}$, and analyzed according to Lowry et al. ${ }^{16)}$ with bovine serum albumin as the reference protein.

\section{RESULTS AND DISCUSSION}

\section{Analysis of proteins by polyacrylamide gel electrophoresis}

Uritani \& Stahmann ${ }^{1)}$ separated the soluble proteins of sweet potato roots into several bands by starch gel electrophoresis, but without good resolution. We tried to separate them by SDS and nondenaturing polyacryl- 


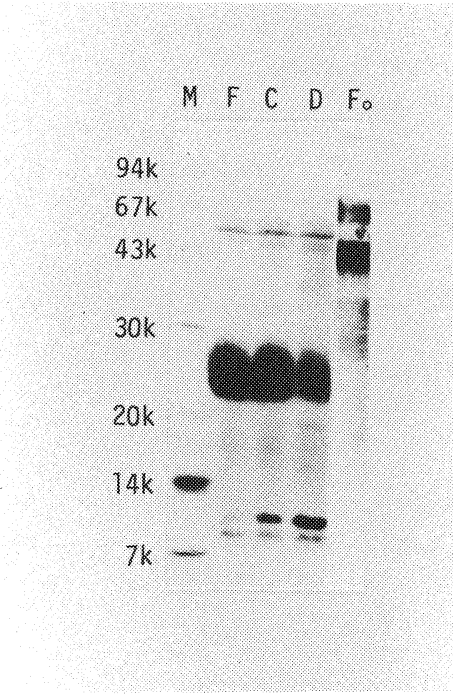

FIG. 1. SDS Polyacrylamide Gel Electrophoresis of Total Soluble Proteins from Fresh (F), Cut (C), Diseased (D), and Stored (Fo) Sweet Potato Root Tissues.

Each lane was loaded with $100 \mu \mathrm{g}$ of protein. Molecular weight markers appear in lane $\mathbf{M}$.

amide gel electrophoresis. SDS polyacrylamide gel electrophoresis separated the proteins of fresh roots into one major band, a few prominent bands, and many minor bands (lane $F$ in Fig. 1). The major protein had an apparent molecular weight of 25,000 and was designated the $25-\mathrm{kDa}$ protein. Its amount was less while that of lower-molecular-weight proteins in the range of 9,500 to 20,000 was greater in cut and diseased tissue extracts (lanes C and D in Fig. 1). A very different pattern of proteins was found in tissue extract from stored roots; hardly any $25-\mathrm{kDa}$ protein was detected (lane Fo in Fig. 1).

Native proteins in cut, diseased, and stored tissues may be degraded by protease during the extraction procedure, so we extracted soluble proteins from sweet potato root tissues in the presence of phenylmethylsulfonyl fluoride, $p$ chloromercuribenzoate, and ethylenediaminetetraacetic acid, all $1 \mathrm{~mm}$. Figure 2 shows that the protein patterns of the total soluble proteins on SDS gel for proteins extracted by the buffer with or without protease inhibitors were the same. Thus, the changes in the protein patterns of tissue extracts following cutting,

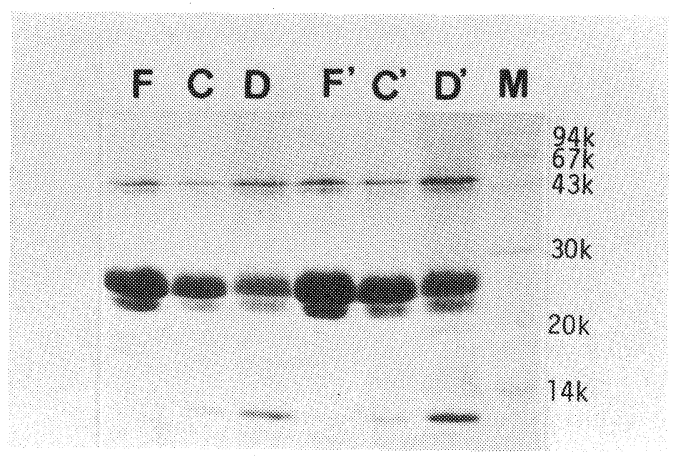

FIG. 2. Effect of Addition of Protease Inhibitors during Protein Extraction on Protein Patterns after SDS Polyacrylamide Gel Electrophoresis.

Lanes F, C, and D: Soluble protein $(75 \mu \mathrm{g})$ extracted in the absence of protease inhibitors from fresh, cut, and diseased tissues, respectively. Lane $\mathrm{F}^{\prime}, \mathrm{C}^{\prime}$, and $\mathrm{D}^{\prime}$ : Soluble protein $(75 \mu \mathrm{g})$ extracted in the presence of phenylmethylsulfonyl fluoride, $p$-chloromercuribenzoate, and ethylenediaminetetraacetic acid (all $1 \mathrm{~mm}$ ) from fresh, cut, and diseased tissues, respectively. Lane $\mathrm{M}$ : molecular weight markers.

infection, and storage are the result of changes in situ.

We estimated the amount of total soluble proteins and of major proteins (such as the 25$\mathrm{kDa}$ protein and the protein with a molecular weight of 9,500 , called the $9.5-\mathrm{kDa}$ protein) in fresh, cut, diseased, and stored tissue extracts. The amount of total soluble proteins did increase in cut and diseased tissues, as reported previously, ${ }^{1)}$ but decreased in stored tissue (Table I). The $25-\mathrm{kDa}$ protein represented about $60 \%$ of the total soluble proteins of fresh tissue. We also found that the decrease in 25$\mathrm{kDa}$ protein in the tissue following cutting or infection was nearly the same as the increase in $9.5-\mathrm{kDa}$ protein; the extent of the change is greater in diseased tissue. These results indicate that the $25-\mathrm{kDa}$ protein is degraded to proteins of lower molecular weight upon cutting or infection of the tissue.

Nondenaturing polyacrylamide gel electrophoresis separated the soluble proteins of sweet potato root tissues into bands, which we numbered 1 to 15 (Fig. 3). Two proteins located in bands 9 and 10 were the major proteins in fresh tissue extract. The band 9 and 10 proteins decreased while the band $11 \sim 14$ 
Table I. Amounts of Total, 25-kDa, and 9.5-kDa Proteins of Sweet Potato Root Tissue and Changes Following Cutting, C. fimbriata INFECTION, AND STORAGE

\begin{tabular}{|c|c|c|c|c|}
\hline Tissue & Fresh & Cut & Diseased & Stored \\
\hline $\begin{array}{l}\text { Total soluble protein } \\
\text { (mg/g tissue) }\end{array}$ & 5.22 & 5.76 & 6.39 & 4.50 \\
\hline \multicolumn{5}{|l|}{$25-\mathrm{kDa}$ protein } \\
\hline$\%$ of total protein ${ }^{a}$ & 61.7 & 50.9 & 36.8 & 4.06 \\
\hline $\mathrm{mg} / \mathrm{g}$ tissue $^{b}$ & 3.22 & 2.93 & 2.35 & 0.18 \\
\hline $\mathrm{nmol} / \mathrm{g}$ tissue & 129 & 117 & 94.0 & 7.2 \\
\hline $\begin{array}{l}\text { Change relative to fresh tissue } \\
\text { (nmol/g tissue) }\end{array}$ & - & -12 & -35 & -122 \\
\hline \multicolumn{5}{|l|}{$9.5-\mathrm{kDa}$ protein } \\
\hline$\%$ of total protein ${ }^{a}$ & 1.82 & 6.40 & 13.2 & 4.70 \\
\hline $\mathrm{mg} / \mathrm{g}$ tissue $^{b}$ & 0.10 & 0.36 & 0.84 & 0.21 \\
\hline $\mathrm{nmol} / \mathrm{g}$ tissue & 4.0 & 14.4 & 33.6 & 8.4 \\
\hline $\begin{array}{l}\text { change relative to fresh tissue } \\
\text { (nmol/g tissue) }\end{array}$ & - & +10 & +30 & +4.0 \\
\hline
\end{tabular}

a Values calculated from densitometer scan data of the gels after staining with Coomassie blue.

$b$ The protein content of the total soluble extract was determined and densitometric readings (percent of area under curves) were converted to weight of individual protein bands.

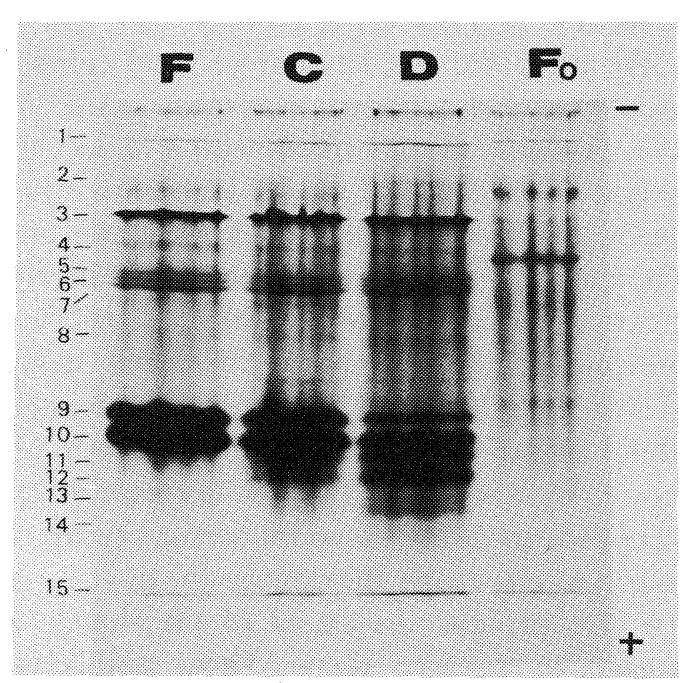

FIG. 3. Nondenaturing Polyacrylamide Gel Electrophoresis ( $\mathrm{pH} 8.9$ ) of Total Soluble Proteins from Fresh (F), Cut (C), Diseased (D), and Stored (Fo) Sweet Potato Root Tissues.

Each lane of the 2-mm slab gel was loaded with $1 \mathrm{mg}$ of protein.

proteins increased in cut and diseased tissue extracts. The major proteins had almost disappeared from stored tissue extract. The amount of band 3 protein, one of the major proteins in fresh tissue, was not appreciably affected by cutting or infection, but clearly decreased during storage.

The molecular weights of these major proteins separated by nondenaturing polyacrylamide gel electrophoresis were found by separately eluting the protein in each band from the gel strip, denaturing it, and subjecting it to SDS polyacrylamide gel electrophoresis. Figure 4 shows that the molecular weights of the band 3,5, and 9 proteins were 50,000, 45,000 , and 25,000, respectively. The molecular weight of the band 10 protein also was 25,000 (data not shown). Band 12 protein included one major protein with the molecular weight of 25,000 and a few minor proteins with molecular weights of 9,500 to 20,000 (lane 12 in Fig. 4). Band 14 protein contained mainly $9.5-\mathrm{kDa}$ protein and some 20 to $25-\mathrm{kDa}$ proteins (lane 14 in Fig. 4). Bands 13 and 14 contanied more $9.5-\mathrm{kDa}$ protein than bands 11 and 12 . The appearance of $25-\mathrm{kDa}$ and smaller fragments on denaturing gels (lanes 12 and 14 in Fig. 4) may be explained if native proteins (bands 9 and 10) are multi- 
meric proteins and if the proteins of bands $11 \sim 14$ are also, one or more of the subunits having been cleaved to smaller fragments.

\section{Immunochemical analysis of major proteins}

To examine the immunochemical relationship of proteins separated by nondenaturing polyacrylamide gel electrophoresis, we used both the Ouchterlony double-diffusion test and also crossed immunoelectrophoresis with antibodies to the total soluble proteins from diseased tissue and to the band 9 protein of fresh tissue. Three distinct precipitin lines $(\mathrm{a}, \mathrm{b}$,

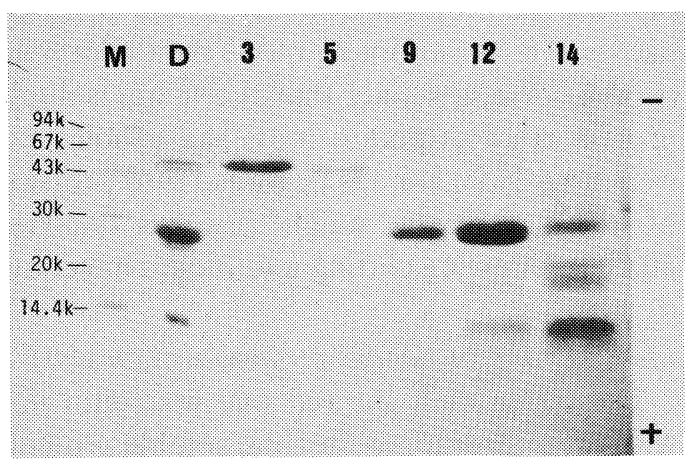

FIG. 4. SDS Polyacrylamide Gel Electrophoresis of Proteins Separated by Nondenaturing Polyacrylamide Gel Electrophoresis.

The numbers above the lanes indicate the numbers of protein bands on the slab gel after nondenaturing polyacrylamide gel electrophoresis of total soluble protein from diseased tissue (see Fig. 3). Lanes M and D, molecular weight markers and total soluble proteins from diseased tissue, respectively. and c) were observed between the antiserum to total soluble proteins from diseased tissue and extracts from fresh, cut, and diseased tissues (Fig. 5). No specific precipitin patterns were found between diseased tissue extract and its own antiserum, although Uritani and Stahmann ${ }^{1,2)}$ reported the presence of two distinct precipitin lines designated lines $\mathrm{B}$ and D. Also, no specific precipitin pattern between diseased tissue extract and its antiserum was seen by crossed immunoelectrophoresis of proteins from fresh and diseased tissue (Fig. 6).

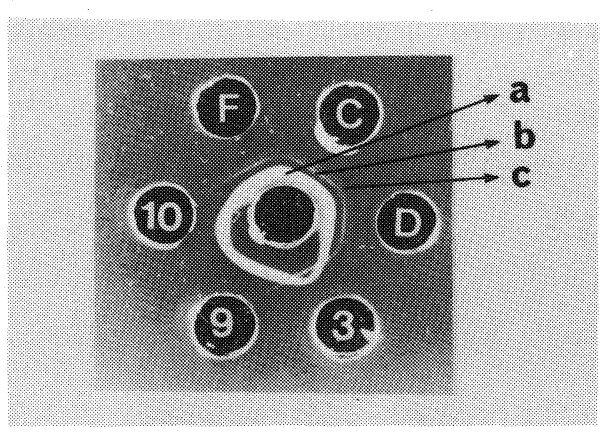

FIG. 5. Ouchterlony Double Immunodiffusion Test.

The center well contained antiserum to total soluble protein from diseased tissue.

Surrounding wells contained soluble proteins from fresh (F), cut (C), and diseased (D) tissues, and proteins eluted from the gels affer nondenaturing polyacrylamide gel electrophoresis of total soluble protein from the tissues. Numbers indicate the number of protein bands on the slab gel (see Fig. 3).

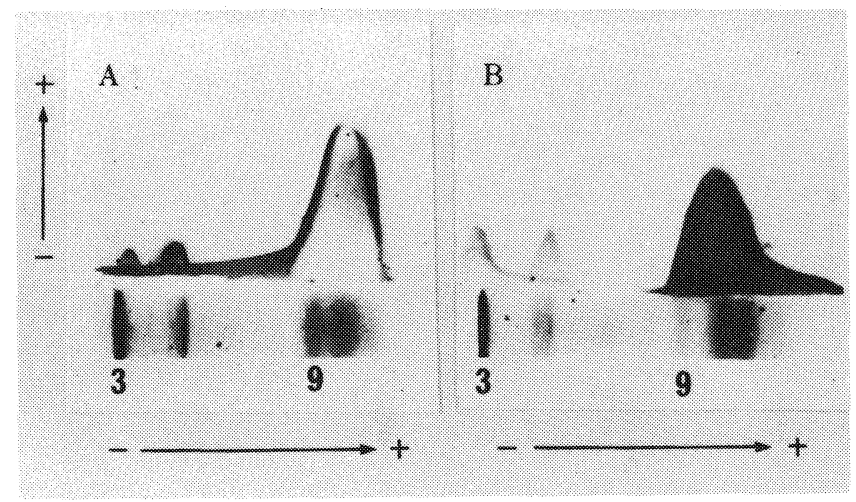

FIG. 6. Crossed Immunoelectrophoresis of Total Soluble Proteins from Fresh (A) and Diseased (B) Tissues Using Antiserum to Total Soluble Proteins from Diseased Tissue.

A gel stained after nondenaturing polyacrylamide gel electrophoresis in the first run is shown at the bottom of the figure for comparison. 
Band 9 and 10 proteins showed one continuous precipitin line with the antiserum to the total soluble proteins, forming the continuous arc of line (a) in Fig. 5. Line (a) was identified by Dr. Uritani as being the same as line A reported by Uritani and Stahmann. ${ }^{1,2)}$ Antigenic component $\mathrm{A}$, which is assumed to be a storage protein, ${ }^{17)}$ was thus identified as the $25-\mathrm{kDa}$ protein. Band 9 and 10 proteins may correspond to antigenic components $A_{1}$ and $\mathrm{A}_{2} \cdot{ }^{1)}$ Proteins of bands 9 and 10 showed one precipitin line with the antiserum to band 9 protein, forming a continuous arc (Fig. 7). Therefore, the major soluble protein (the 25$\mathrm{kDa}$ protein) of sweet potato root seems to exist as two isomers, as is true for the storage protein of both potato and yam tubers. ${ }^{8,9)}$

As described above, band 9 and 10 proteins

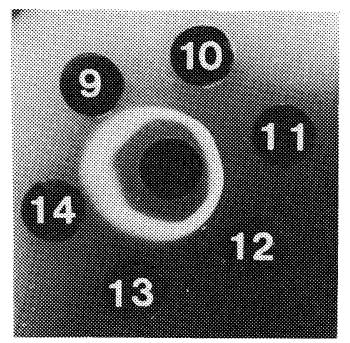

FIG. 7. Ouchterlony Double Immunodiffusion Test.

The center well contained antiserum to band 9 protein. Surrounding wells contained proteins eluted from gels after nondenaturing polyacrylamide gel electrophoresis of total soluble proteins from diseased tissue. Numbers indicate the number of protein bands on the slab gel (see Fig. 3). decreased while new bands (bands 11 to 14) increased after cutting or infection. To find if these new proteins were derived from band 9 protein, immunodiffusion tests between the antiserum to band 9 protein and each new protein in bands $11 \sim 14$ were conducted as shown in Fig. 7. Proteins of bands 11 to 14 showed one precipitin line with the antiserum to band 9 protein, forming a continuous arc. Thus the proteins in bands 11 to 14 had parts immunologically identical with $25-\mathrm{kDa}$ protein and were most likely derived from it. This was confirmed by crossed immunoelectrophoresis of proteins from fresh and diseased tissues with the antibody to the band 9 protein (Fig. 8). We conclude that the major soluble protein of sweet potato roots has a molecular weight of 25,000 and is degraded into proteins of lower molecular weight proteins $(9,500$ $20,000)$ following cutting and fungal infection.

\section{Identification of band 3 protein as $\beta$-amylase}

Band 3 protein showed one precipitin line with the antiserum to the total soluble proteins from diseased tissue, forming a continuous arc with line (b) in Fig. 5. In the immunodiffusion test, both band 3 protein and $\beta$-amylase (SERVA FeinBiochemica, Heidelberg) showed one precipitin line with the antiserum to the total soluble proteins from diseased tissue, forming a continuous are (Fig. 9A). Thus, band 3 protein was identified as $\beta$-amylase. This was confirmed by immunoelectrophoresis

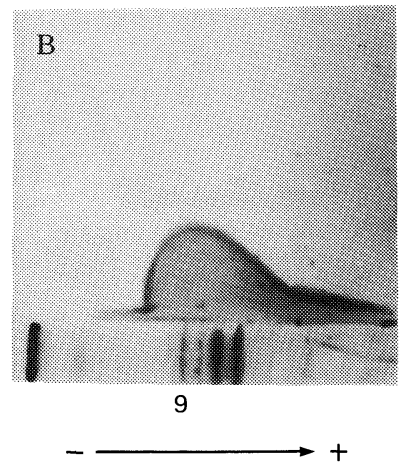

FIG. 8. Crossed Immunoelectrophoresis of Total Soluble Proteins from Fresh (A) and Diseased (B) Tissues Using Antibody to Band 9 Protein.

A gel stained after electrophoresis in the first run is shown at the bottom of the figure for comparison. 


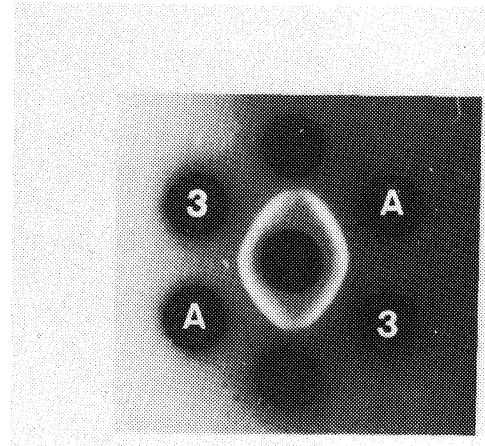

A

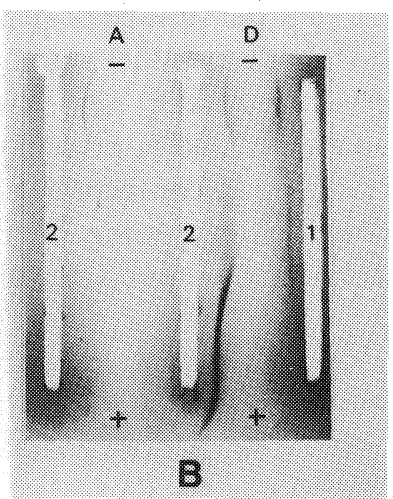

FIG. 9. Ouchterlony Double Immunodiffusion Test (A) and Immunoelectrophoresis (B) of $\beta$-Amylase and Total Soluble Proteins from Diseased Tissue.

The center well of Fig. 9A contained antiserum to total soluble proteins from diseased tissue. Surrounding wells contained $\beta$-amylase (A) and band 3 protein (3). Lanes A and D of Fig. 9B were gel strips after electrophoresis of $\beta$-amylase and total soluble proteins from diseased tissue respectively were embedded. Wells 1 and 2 contained antiserum to total soluble proteins from fresh and diseased tissues, respectively.

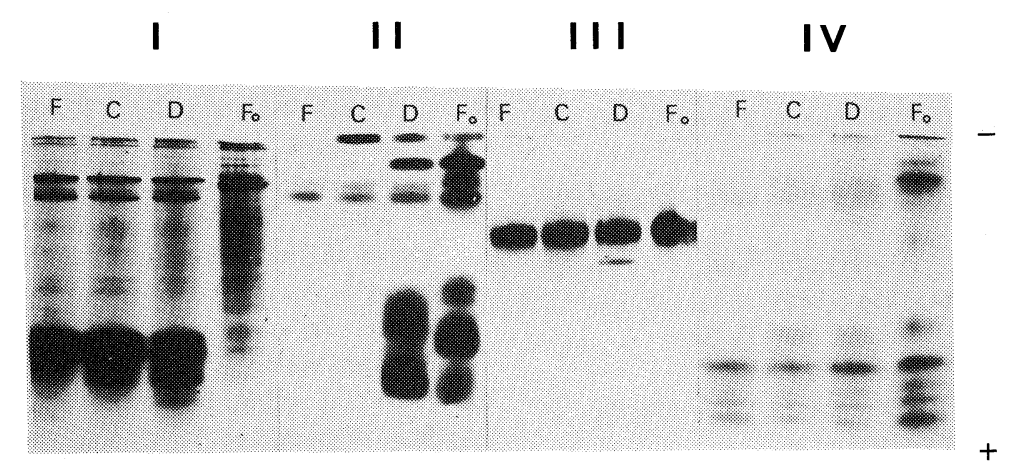

FIG. 10. Polyacrylamide Gel Electrophoresis of Total Soluble Proteins Extracted from Fresh (F), Cut (C), Diseased (D), and Stored (Fo) Tissues.

I, protein patterns; II, zymograms of peroxidase; III, zymograms of phosphatase; IV, zymograms of esterase. Each lane of the 1-mm slab gel was loaded with $70 \mu \mathrm{g}$ of protein.

of $\beta$-amylase and the total soluble proteins of diseased tissue (Fig. 9B).

Formation of new isozymes of peroxidase, phosphatase, and esterase following cutting, $C$. fimbriata infection, or storage

Zymograms of peroxidase, phosphatase, and esterase (Fig. 10) showed that new isozymes of peroxidase ${ }^{1,3)}$ and esterase were formed in cut, diseased, or stored tissues, with notable increases in these enzyme activities in tissue extract from diseased or stored tissue. There was one new isozyme of phosphatase formed in diseased tissue.

When subjected to injury such as cutting or pathogenic infection, sweet potato root tissue adjacent to the cut surface or the infected area undergoes various metabolic changes. Many enzymes such as phenylalanine ammonialyase, acid invertase, polyphenol oxidase, cytochrome oxidase, catalase, and peroxidase are synthesized de novo after cutting, and incorporation of ${ }^{14} \mathrm{C}$-labeled amino acid into TCAinsoluble proteins increased drastically after cutting or $C$. fimbriata infection. ${ }^{17 \sim 19)}$ Therefore, it was assumed without data yet 
being made available that the storage proteins were degraded into small peptides (amino acids) and re-utilized to make new proteins. ${ }^{17,20)}$ Our finding that $25-\mathrm{kDa}$ protein of sweet potato root is degraded into peptides of lower molecular weight after cutting or infection is the first evidence supporting this assumption.

This $25-\mathrm{kDa}$ protein should be a useful marker in attempts to breed sweet potato with a high protein content, a major goal of breeders.

Acknowledgments. The authors wish to thank Dr. I. Uritani, Professor Emeritus, Nagoya University, and the members of this laboratory for their encouragement and stimulating discussions. They are also indebted to Dr. M. Maeshima of this laboratory for providing the antiserum to band 9 protein.

\section{REFERENCES}

1) I. Uritani and M. A. Stahmann, Plant Physiol., 36, 770 (1961).

2) I. Uritani and M. A. Stahmann, Agric. Biol. Chem., 25, 479 (196i).

3) N. Kawashima, H. Hyodo and I. Uritani, Phytopathology, 54, 1086 (1964).

4) K. Nakasone, R. Hayashi and T. Hata, J. Agric. Chem. Soc. Jpn., 46, 45 (1972).

5) H. Stegeman, H. Francksen, V. Macko, $Z$. Naturforsh., 28, 722 (1973).

6) D. Racusen and M. Foote, J. Food Biochem., 4, 43
(1980).

7) E. Paiva, R. M. Lister and W. D. Park, Plant Physiol., 71, 161 (1983).

8) W. D. Park, C. Blackwood, G. A. Mignery, M. A. Hermodson and R. M. Lister, Plant Physiol., 71, 156 (1983).

9) P. J. Harvey and D. Boulter, Phytochemistry, 22, 1687 (1983).

10) U. K. Laemmli, Nature, 227, 680 (1970).

11) B. J. Davis, Ann. N. Y. Acad Sci., 121, 404 (1964).

12) E. Engvall, "Methods in Enzymology," Vol. 70 , ed. by H. V. Vunakis and J. J. Langone, Academic Press, New York, 1980, p. 419.

13) T. Endo, B. B. Shaht and C. Pai, Jpn. J. Genet., 46, 147 (1971).

14) A. L. Kahler and R. W. Allard, Crop Sci., 10, 444 (1970).

15) Ö. Ouchterlony and L. Å. Nilson, "Handbook of Experimental Immunology," ed. by D. M. Weir, Blackwell Scientific Publication, Oxford, 1973, p. 19.1 .

16) O. H. Lowry, N. J. Rosebrough, A. L. Farr and R. J. Randall, J. Biol. Chem., 193, 265 (1951).

17) I. Uritani, Annl. Rev. Phytopathology, 9, 211 (1971).

18) I. Uritani, "Encyclopedia of Plant Physiology," Vol. 4, ed. by R. Heitefuss, P. H. Williams, SpringerVerlag, Berlin, Heidelberg, New York, 1976, p. 509.

19) K. Ôba, R. Yu, M. Fujita and I. Uritani, "Plant Infection: The Physiological and Biochemical Basis," ed. by Y. Asada, W. R. Bushnell, S. Ouchi and C. P. Vance, Japan Scientific Societies Press, Tokyo, Springer-Verlag, Berlin, 1982, p. 159.

20) I. Uritani and K. Ôba, "Biochemistry of Wounded Plant Tissues," ed. by G. Kahl, Walter de Gruyter, Berlin, New York, 1978, p. 287. 